\title{
COMPARATIVE STUDY OF THE EMISSION CHARACTERIZATION OF BIOGAS AND CONVENTIONAL COOKING GAS IN NIGERIA
}

\author{
Titus Adegboye $^{1 *}$ and Iyiola Oluwaleye ${ }^{2}$ \\ ${ }^{1}$ Department of Mechanical Engineering Technology, Federal Polytechnic Ede, Nigeria \\ ${ }^{2}$ Department of Mechanical Engineering, Ekiti State University Ado-Ekiti, Nigeria \\ *corresponding author: adeleyeadegboye@gmail.com, +2348068538815
}

\begin{abstract}
Household fuel refers to any material that is used to produce heat or power by burning. Some of the household fuel used in Nigeria includes: biomass, charcoal, kerosene, CNG (Compressed natural gas), LPG (liquefied petroleum gas), electricity. Biogas is relatively new and emerging as a viable option. In this study, biogas was produced using cow dung and the emission characterization of biogas and that of LPG was compared using a Gasboard model $5020 \mathrm{H}$ gas analyzer. Results of biogas emission is as follows; $\mathrm{CO}: 0.01 \% \mathrm{Vol}, \mathrm{CO}_{2}: 0.14 \% \mathrm{Vol}, \mathrm{HC}: 0010$ ppm, $\mathrm{NO}_{x:} 0002 \mathrm{ppm}$ while LPG gives the following; CO: 0.30\% Vol , $\mathrm{CO}_{2:} 1.88 \% \mathrm{Vol}, \mathrm{HC}$ : 0003 ppm, NO 0007 ppm. Recommendation was made for the inclusion of biogas in Nigeria energy mix because of its relatively better emission.
\end{abstract}

Key words: Household Fuel, Household air Pollution, Emission Characterisation, Renewable Energy. 


\section{Introduction}

Household fuel refers to any material that is used to produce heat or power by burning (Timilsina, 2014). The energy situation in developing countries shows that more energy is consumed for cooking than any other sector (Outlook, 2006) (Diaoglou, 2012). Studies show that in Nigeria energy consumed by the household sector is about $80 \%$ of the national energy consumption in 2015 which is to the tune of 97661 ktoe (IAE, 2017) (Dioha, 2018) . Furthermore, the most intensive energy consuming activity in the Nigerian household is cooking and this is made up of $90 \%$ biomass (charcoal, firewood, cow dung etc.) (Dioha, 2018).

Generally, household cooking energy are usually classified in a number of ways:

a) Traditional, intermediate and modern fuels. Traditional fuels would include basic energy sources like fuelwood, animal dung and agricultural residue. Intermediate sources are coal, kerosene and charcoal while moderns includes: CNG (Compressed natural gas), LPG (liquefied petroleum gas, electricity, solar, natural gas).

b) Primary and secondary fuels. Primary fuels are those fuels which are obtained from natural sources. These would include solar energy, fuelwood, animal dung, natural gas and coal. Secondary energy sources obtained by treating or processing primary fuels, ethanol from agricultural produce; kerosene, LPG from petroleum and charcoal from wood.

c) Renewable and non-renewable: solar energy, biogas and biomass fall within the renewable class while kerosene, LPG CNG are non-renewable (Timilsina, 2014).

\section{POLUTANT}

Ajeigbe, et al (2014) identified two classes of air pollutants: primary pollutants which are emission products released directly into the atmosphere and secondary pollutants on the other hand are formed in the atmosphere by the reaction of the primary pollutants. Primary pollutants include compounds of nitrogen, carbon, sulphur and halogen compounds. Compounds of nitrogen include $\mathrm{NO}, \mathrm{N}_{2} \mathrm{O}$, and $\mathrm{NH}_{3}$. Compounds of carbon on the other hand include $\mathrm{CO}, \mathrm{CO}_{2}$, $\mathrm{CH}_{4}$, and VOCs. Compounds of sulphur, $\mathrm{H}_{2} \mathrm{~S}$ and $\mathrm{SO}$, halogen compounds, chlorides, fluorides, and bromides.

Secondary polutants are: $\mathrm{NO}_{2}$ and $\mathrm{HNO}_{3}$ formed from $\mathrm{NO}$, Ozone $\left(\mathrm{O}_{3}\right)$, VOCs, Sulphuric acid droplets, NH3 droplets, Sulphates and nitrates aerosols (Ajeigbe et al, 2014) (Daly et al, 2007) (Bailey, 2010).

In recent times a lot of efforts have been devoted to sources of alternative energy as opposed to conventional energy sources, in view of the adverse effect of continuous use of conventional fuel on human life and the environment. Research effort has focused on cleaner energy sources (Ovueni, 2014).

Studies show that conventional household fuels such as fuel wood, coal and biomass have serious implication on human health, climate change and forest degradation. In 2010 an estimated 3.5 million deaths was as a result of household air pollution as a result of the use of solid fuel. In Asia and Sub-Sahara Africa an estimated 500,000 deaths resulted from outdoor air. U J Ovueni (2014) identified the following gases as green house: Carbon Dioxide $\left(\mathrm{CO}_{2}\right)$, Methane $\left(\mathrm{CH}_{4}\right)$, Nitrous Oxide $\left(\mathrm{N}_{2} \mathrm{O}\right)$, Fluorinated Gases which include sulphur hexafluoride 
Hydrofluorocarbons and perfluorocarbon. Some of the effects of green house gases include global warming, climatic transformation and thermal imbalance (Aderogba, 2011).

\section{BIOGAS}

The production of biogas is from the anaerobic digestion of natural organic matter. Some of the common organic matter used includes: cow dung, rabbit dropping, poultry litter and kitchen waste. Apart from the set up producing biogas which is a methane rich fuel used for domestic cooking. The residual sludge is used as fertilizer as it is rich in organic nitrogen. Biogas is used for domestic cooking, generation of electricity and as automobile fuel (Beschkov, 2020) (Putris, 2012).

Table 1 showing the constituent of biogas (Ray, 2016)

\begin{tabular}{|l|l|}
\hline Substances & Biogas \% \\
\hline Methane $\left(\mathrm{CH}_{4}\right)$ & $50-60$ \\
\hline Carbon Dioxide $\left(\mathrm{CO}_{2}\right)$ & $34-38$ \\
\hline Nitrogen $\left(\mathrm{N}_{2}\right)$ & $0-5$ \\
\hline Water Vapour $\left(\mathrm{H}_{2} \mathrm{O}\right)$ & 6 \\
\hline Hydrogen Sulphide $\left(\mathrm{H}_{2} \mathrm{~S}\right)$ & Trace \\
\hline
\end{tabular}

LPG

LPG is a hydrocarbon mixture of propane and butane in varying proportion depending on seasons and fields. At normal temperature and a pressure between 8.5 and 9.0 atmospheres LPG can be liquefied. The total pressure of the LPG and its thermal energy is affected by the mixing ratio of the propane and butane (Chaichan, 2017).

This write up seeks to examine and compare the emission characterization of LPG and biogas produced from cow dung.

\subsection{Materials and method}

The LPG gas was purchased from the open market as it is readily available. In general, LPG is a mixture of gases: propane $\left(\mathrm{C}_{3} \mathrm{H}_{8}\right)$ and butane $\left(\mathrm{C}_{4} \mathrm{H}_{10}\right)$ and a small part of ethane $\left(\mathrm{C}_{2} \mathrm{H}_{6}\right)$ or pentane $\left(\mathrm{C}_{5} \mathrm{H}_{12}\right)$. It is stored as a liquid in pressurized cylinders (Muji, 2017). It is sold in the LPG cylinder of $3 \mathrm{Kg}, 12.5 \mathrm{~kg}$ and $50 \mathrm{~kg}$ cylinders. An LPG stove was used to burn the gas and the emission analysed using a gas analyser. 


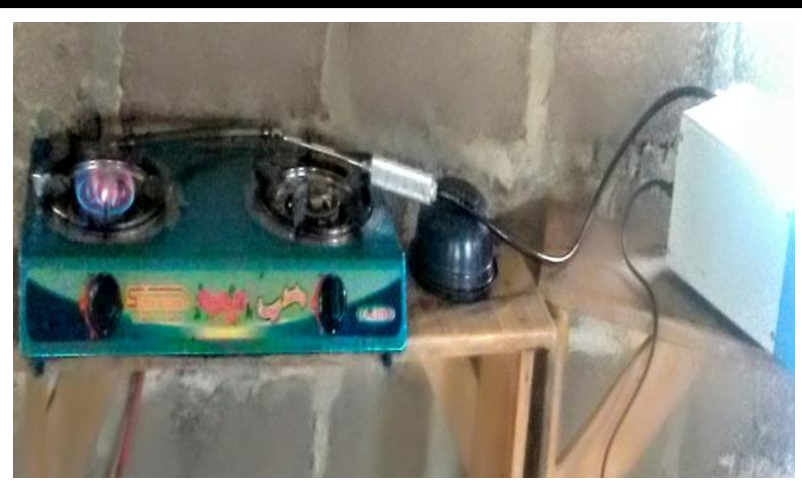

Fig. 1: Set up for LPG emission characterization

The biogas used in this investigation was produced using a bio-digester. The bio-digester is made up of $0.83 \mathrm{~m}^{3}$ plastic drum with one inlet for recharging and two outlet ports: for biogas and degraded dung. It was positioned outdoor as higher temperature enhances biogas generation. The biogas was stored in a tyre tube. The schematic arrangement is as shown below:

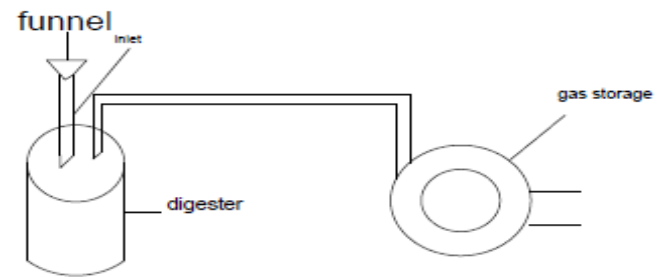

Fig. 2 : Schematic diagram of digester for the production of biogas

An LPG burner was adapted for biogas in this work.

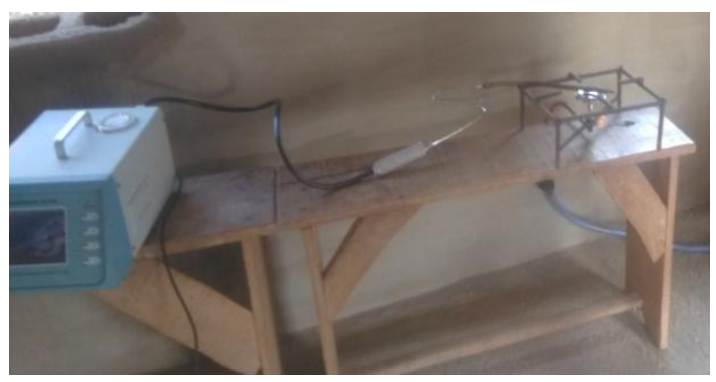

Fig. 3: Set up for biogas emission characterization.

A Gasboard model $5020 \mathrm{H}$ automobile gas analyzer with the infrared system was used in the experiments. The device has the potential to analyze and measure exhaust gases emissions of gasoline vehicles which include: Hydrocarbon (HC), Carbon Monoxide (CO), Carbon Dioxide $\left(\mathrm{CO}_{2}\right)$, oxygen $\left(\mathrm{O}_{2}\right)$ and Nitrogen Oxide $\left(\mathrm{NO}_{\mathrm{x}}\right)$. The technical specification of the Gasboard model $5020 \mathrm{H}$ automobile gas analyzer is given in Table. 2 . 
Table 2: The Specifications of the Exhaust Gas Analyzer

\begin{tabular}{|l|l|l|}
\hline Analysis & Measuring range & Resolution \\
\hline $\mathrm{CO}$ & $0.00-10.00 \%$ & $0.01 \%$ vol \\
& vol & \\
\hline $\mathrm{HC}$ & $0-9999.00 \mathrm{ppm}$ & $0.01 \%$ vol \\
& vol & \\
\hline $\mathrm{CO}_{2}$ & $0.00-20.00 \%$ & $0.01 \%$ vol \\
\hline $\mathrm{O}_{2}$ & vol & \\
\hline Lambda & $0.50-2.50$ & 0.01 \\
display & & vol \\
\hline
\end{tabular}

\subsection{RESULT}

Table 3: Exhaust emission of LPG and biogas.

\begin{tabular}{|l|l|l|}
\hline EXHAUST & LPG & BIOGAS \\
\hline $\mathrm{CO}(\%$ vol $)$ & 0.30 & 0.01 \\
\hline $\mathrm{CO}_{2}(\%$ vol $)$ & 1.88 & 0.14 \\
\hline $\mathrm{HC}(\mathrm{ppm})$ & 0003 & 0010 \\
\hline $\mathrm{NO}_{\mathrm{x}}(\mathrm{ppm})$ & 0007 & 0002 \\
\hline
\end{tabular}

\subsection{Discussion on result}

The Gasboard model $5020 \mathrm{H}$ gas analyzer used in this study analysed $\mathrm{CO}, \mathrm{CO}_{2}, \mathrm{HC}$ and $\mathrm{NO}_{\mathrm{X}}$ from the exhaust emission of the household fuels. The levels of Carbon monoxide emission give 
good criteria for the ranking of household fuel in terms of emission quality (Bamidele et al, 2019) (Ezzati, 2000).

\section{$\underline{\text { Emission of CO }}$}

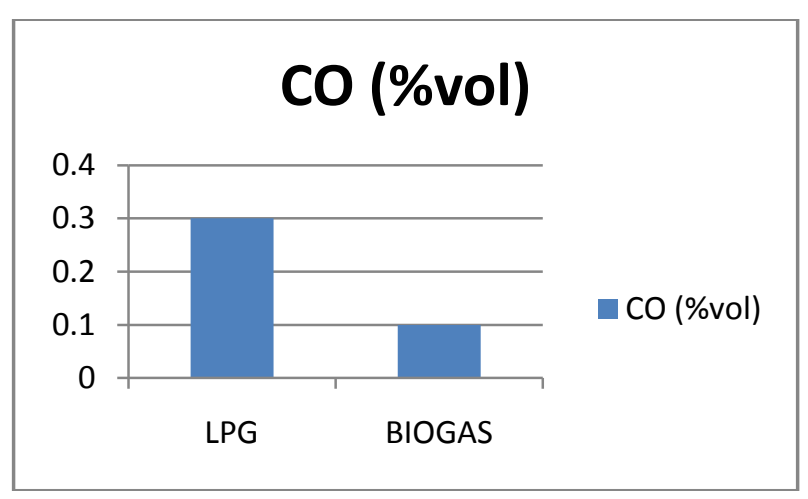

Fig. 4: Comparison of CO emissions of LPG and Biogas

The emission of $\mathrm{CO}$ can be largely due to incomplete combustion as a result of insufficient oxygen, and moisture content (Bamidele et al, 2019) (Tissari, 2009). In this study it is observed that LPG has a higher CO emission. This agrees with the work of Nwaokocha et al. (2018). LPG although is a colorless gas comprises of a number of hydrocarbons mainly propane and butane, hence its higher value (Piotr et al., 2001).

\section{$\underline{\text { Emission of } \mathrm{CO}_{2}}$}

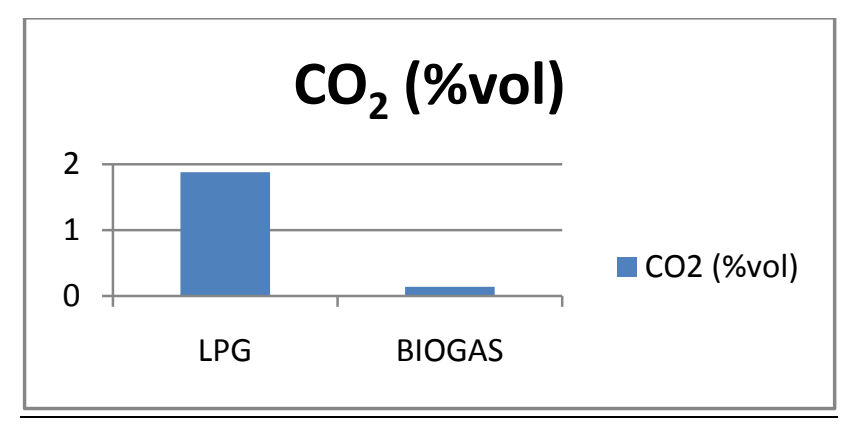

Fig. 5: Comparison of $\mathrm{CO}_{2}$ emissions of LPG and Biogas

The conversion of $\mathrm{CO}$ to the $\mathrm{CO}_{2}$ is a likelihood in as much as there is sufficient oxygen. LPG higher $\mathrm{CO}_{2}$ emission could be because it is fed from a pressurized container compared to the biogas a low pressure gas. 


\section{Emission of $\mathrm{NO}_{2}$}

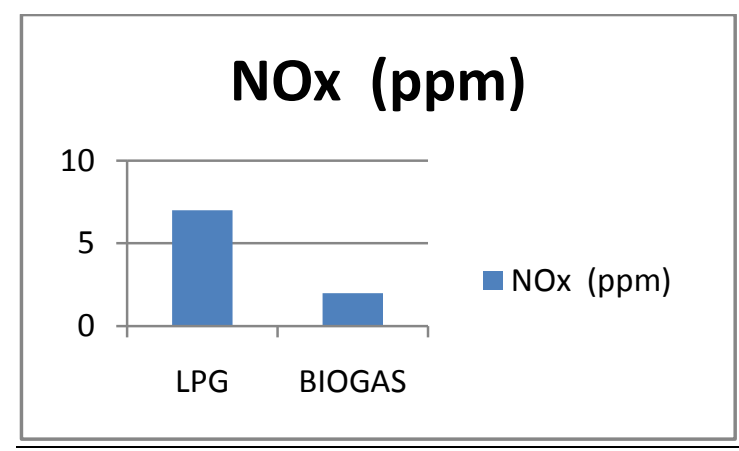

Fig. 6: Comparison of $\mathrm{NO}_{\mathrm{X}}$ emissions of LPG and Biogas

$\mathrm{NO}_{\mathrm{X}}$ emission is basically due to the presence of nitrogen in the combusted air. In this work it is observed that LPG emission of Nitrogen is higher when compared to biogas.

\section{Emission of HC}

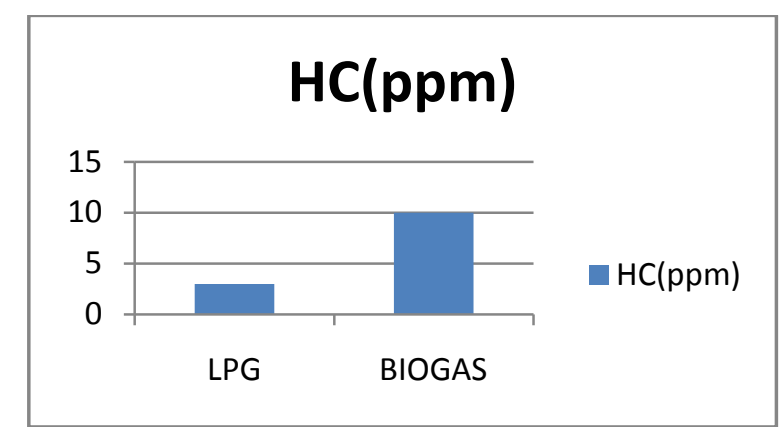

Fig. 7: Comparison of HC emissions of LPG and Biogas

The $\mathrm{HC}$ emissions are due to the unburnt fuel particles. The emission of $\mathrm{HC}$ was observed to be higher with biogas. This disagrees with the work of Nwaokocha et al. (2018).

\subsection{Conclusions and recommendation}

The study compares the emission characterization of LPG with biogas and provides information on gaseous air pollutants associated with the combustion of the two energy sources.

Experimental tests were carried out using A Gasboard model $5020 \mathrm{H}$ gas analyzer. Results obtained in this study show that LPG though a good energy source but in respect to household air pollution biogas yields a better result. Though Bamidele et al. (2019) recommended the use of LPG could serve in Nigeria as a source of cooking energy with sustainable health and environmental effect, this study however shows that biogas is a better household fuel with less polluting effect on the household air. Biogas use should be encouraged in Nigeria. 


\section{Reference}

Aderogba, K. (2011). Greenhouse gas emissions and sustainability in Lagos Metropolis, Nigeria. 1(2).

AjeigbeO.A., Kulla D.M. and Pam G.Y. (2014, August). Physical characterisation of emission from the combustion of household cooking fuels in Aiyetoro community. International Journal of Science and Engineering Research, 5(ISSN 2229-5518).

Bailey, R. (2010). Carbon monoxide. Retrieved from http://biology.about.com/od/molecularbiology/a/carbon_monoxide.htm/*

Bamidele Sunday Fakkinle, Olawale Daniel Oke, Olayemi Abosede Odunlami, Jacob Ademola Sonibare, Funso Alaba Akeredolu and Olufemi Sunday Oni. . (2019). Emissio vharacterisation and Performance OF CONVEnTIONAL liquified pertroleum gas cookstoveburners . Congent Engineering, 6(1).

Beschkov, S. D. (2020). Biogas as a source of energy and chemicals. IntechOpen.

Chaichan M.T., J. a. (2017). Spark ignition engine performance when fueled with NG, LPG and gasoline.

Daly A. and Zannnetti P. (2007). An introduction to air pollution- Definition, Classification and History. Retrieved December 6th, 2012, from http://environcomp.org/books/chapter/1 aap.pdf

Diaoglou., V. R. (2012). Model projections for household energy use in developing countries. $37(1), 601-615$.

Dioha, M. O. (2018). Modelling th impact of Nigeria household energy policies on energy consumption and $\mathrm{CO}_{2}$ emission.

Ezzati M., S. H. (2000). The contributions of emissions and spartial microenviroments to exposure to indoor air pollution from biomass combustion in Kenya. 108(9).

IAE. (2017). Report of Nigeria balances . International Energy Age (IAE).

Muji Setiyo, S. S. (2017). Characteristic of LPG compositions in the fuel line during discharging process. 1, 112- 121.

Nwaokocha C.N, G. S. (2018). Emissions characterisatics of LPG retrofited generator . 6(3).

Outlook), I. (. (2006). World Energy Outlook. Paris: IEA ( International Energy Agency).

Piotr Bielaczyc, Andrea Szczotka and Henry Brondzinski. (2001). Analysis of exhaust emissions from vehicles fuelled with petrol or LPG and CNG alternatively. 1B(1-2).

Putris D.A., S. R. (2012). Biogas production from cow manure. 1(2), 61-64.

Ray N.H.S., M. M. (2016). Biogas compression and storage system for cooking applications in rural household. 6(2).

Timilsina, S. M. (2014). Household cooking fuel choice and adoption of improved cookstoves in developing countries A Review. The World Bank Development Research Group Enviroment and Energy Team.

Tissari J., H. K. (2009). The effectes of operating conditions on emissions from masonryheaters and sauna stoves. 33(3), 513-520.

U.J.Ovueni. (2014). Comparative Study of the heating capacity of biogas and conventional cooking gas. 3(1), 7-10. 